\title{
Patient satisfaction with healthcare services: Bangladesh perspective
}

\author{
Abdul kader Mohiuddin \\ Secretary and Treasurer, Dr. M. Nasirullah Memorial Trust, Tejgaon, Bangladesh
}

\begin{tabular}{l}
\hline Article Info \\
\hline Article history: \\
Received Nov 15, 2019 \\
Revised Jan 13, 2020 \\
Accepted Feb 12, 2020 \\
\hline
\end{tabular}

\section{Keywords:}

Consultation length

Patient waiting time

Quality of future doctors

Rural health facilities

Unethical drug promotion

\begin{abstract}
Patient satisfaction is a useful measure for providing a quality benchmark for healthcare services. Concern about the quality of healthcare services in Bangladesh has led to a loss of confidence in healthcare providers, low use of public health facilities and increased outflows of patients from Bangladesh to hospitals abroad. The key obstacles to access to health services are insufficient infrastructure and poor quality of existing facilities, lack of medical equipment, scarcity of doctors due to high patient load, long distance to the facilities and long waiting times until facilities have been reached, very short appointment hours, lack of empathy of health professionals, their generally callous and casual attitude, aggressive pursuit of monetary gains, poor levels of competence and, occasionally, disregard for the suffering that patients endure without being able to voice their concerns-all of these service failures are reported frequently in the print media. Such failures can play a powerful role in shaping patients' negative attitudes and dissatisfaction with healthcare service providers and healthcare itself.
\end{abstract}

This is an open access article under the CC BY-SA license.

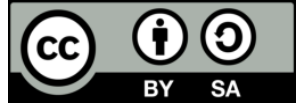

\section{Corresponding Author:}

Absul Kader Mohiuddin,

Secretary and Treasurer,

Dr. M. Nasirullah Memorial Trust, Tejgaon, Dhaka 1215, Bangladesh.

Email: dr.m.nasirullah.trust@gmail.com

\section{INTRODUCTION}

Bangladesh, a lower-center economic system in South Asia, has been encountering a statistic and epidemiological trade with rapid urbanization and a gradual increment in future [1]. It is the seventh most populous in the world. Population is predicted to be nearly double through 2050 [2]. The growing burden of noncommunicable diseases (NCDs) in Bangladesh can be attributable to speedy urbanization and nearly $50 \%$ of all slum dwellers live in Dhaka division [3, 4]. According to World Bank's Country Environmental Analysis (CEA) 2018 report, air pollution lead to deaths of 46,000 humans in yearly in Bangladesh [5]. High stage of pesticides content is existing in grains, pulses, in fruits and vegetables; adulteration mentioned via Institute of Public Health (IPH) in nearly 50\% of market samples [6] and fecal bacteria found in $97 \%$ bottled mineral water [7]. Although there is a declining fashion of toddler malnutrition however the incidence of baby malnutrition is still high [8]. About $2 / 3 \mathrm{rd}$ of the total health expenditure is from out-of-pocket (OOP), and of this, $65 \%$ is spent at the personal drug retail stores [9]. There is little appraisal of the nature of dealer care, low stages of professional statistics and terrible use of abilities. Bangladesh does not have a suited physique for discretion of objections against fitness providers. Hospital or health facility authorities address complaints and disputes independently, except involving the government or felony entities [10]. 'Negligence of Physicians' and 'Wrong Treatment' have become commonly-used phrases in print and 
electronic media of Bangladesh, whilst violence towards the physician in Bangladesh (by sufferers or by means of their associates) has been accelerated and the severity has been intensified simultaneously [11].

\section{RESEARCH METHOD}

Research directed an all year complete writing search, which covered specialized bulletins, newspapers, journals, and numerous exceptional sources. The present study used to be started out at the opening of 2019. PubMed, ALTAVISTA, Embase, Scopus, Web of Science, and the Cochrane Central Register have been fully searched. The keywords were used to search for exclusive publishers' journals such as Elsevier, Springer, Willey Online Library, and Wolters Kluwer which had been notably followed. Medicine and technical experts, pharmaceutical enterprise representatives, clinic nurses, and journalists have been given their precious suggestions. Projections were based totally on patient experience, expectations and motives of dissatisfactions amongst Bangladeshi population with the existing healthcare services.

\section{Present Healthcare Situation}

Harvard Professor Sue Goldie credited Bangladesh for reducing under-5 infant mortality by using $80 \%$, the very best in South Asia and being on goal to attain 2015-MDG5 purpose of lowering maternal mortality ratio of 1990 by means of three-quarters [12]. The current doctor-patient ratio in Bangladesh is only 5.26 to 10,000, that places the us of a at 2nd position from the bottom, among the South Asian countries, in accordance to the WHO [13]. According to Bangladesh Medical and Dental Council, between 2006 and 2018, there have been 25,739 registered male physicians (47\%) and 28,425 female physicians (53\%) in the us of a [14]. Average consultation length is used as an effect indicator in the most important care monitoring device which was located used to be found a much less than a minute to an out of doors affected person [5]. An common 1.5 hours is to spend to see a physician in Dhaka Medical College and other public clinic outdoors, every so often there are no physicians due to publish emptiness [15-17]. Patients' war for integral services during any ailment outbreak in sanatorium indoor and outside is frequent Figure 1. Overall, 67\% of the healthcare price is being paid by using people, whereas international widespread is beneath $32 \%$. Only one clinic bed is allotted per 1667 people, and $34 \%$ of total posts in health region are vacant due to shortage of dollars [18]. In a low socio-economic united states like Bangladesh, nurses fighting in a grossly underfunded healthcare machine to deliver care to the people. Substantial remarkable burdens; absence of authorities convenience and transportation; surprising frailty status; absence of help from nursing directors; absence of advancement openings; insufficient medical health facility strategies and systems; and lack of night time shift and danger allowances suggested by way of Akter et.al, 2019 [19]. Bangladesh Health Facility Survey (BFHS), 2017 exhibits that more than 70\% of rural health facilities do no longer have all six basic equipment objects (thermometers, stethoscopes, blood pressure gauge, weighing scales for toddlers and adults, and torchlights) [20]. Just around half of doctors utilized in public hospitals at region to association sub-focus level are happy with accessibility of medications in their facilities, suggesting widespread lack of medications stocks in public facilities [21]. In 2013/2014, the Infant Mortality Rate, which in urban areas overall is 34 per 1000 live births and 40 in rural areas, rises to almost 70 in urban slum areas [22]. Sir William Osler says "One of the first duties of the physician is to educate the masses not to take medications". Bangladesh has an estimated 100,000 licensed retail drug shops and a further 100,000 unlicensed drug shops [23, 24]. They are largely unregulated and unaccountable, and run by salespersons who are mostly trained informally through a process of 'apprenticeship' [23], where majority of medicines were dispensed irrationally without any prescription and OTC dispensing of many low safety profile drugs is common [25]. More than $80 \%$ of the population seeks care from untrained or poorly trained village doctors and drug shop retailers [24]. The post disaster management in Bangladesh is inadequate due to lack of proper compensation, inadequate or inaccessible healthcare facilities, and the slow rehabilitation process to accommodate the survivors of disasters within the mainstream society [26]. The recent Dengue outbreak caused more than 50,000 hospitalizations in August, 2019 alone [27] and around 100,000 hospitalizations and claimed 112 deaths from January to October, 2019 [28], where hospitals were not able to handle the huge number of patients flooding the hospitals [29]. The country is hosting 1.1 million Rohingya refugees [30], who are posing serious threat of diphtheria [31-33], HIV and other STDs transmission [34, 35]. 


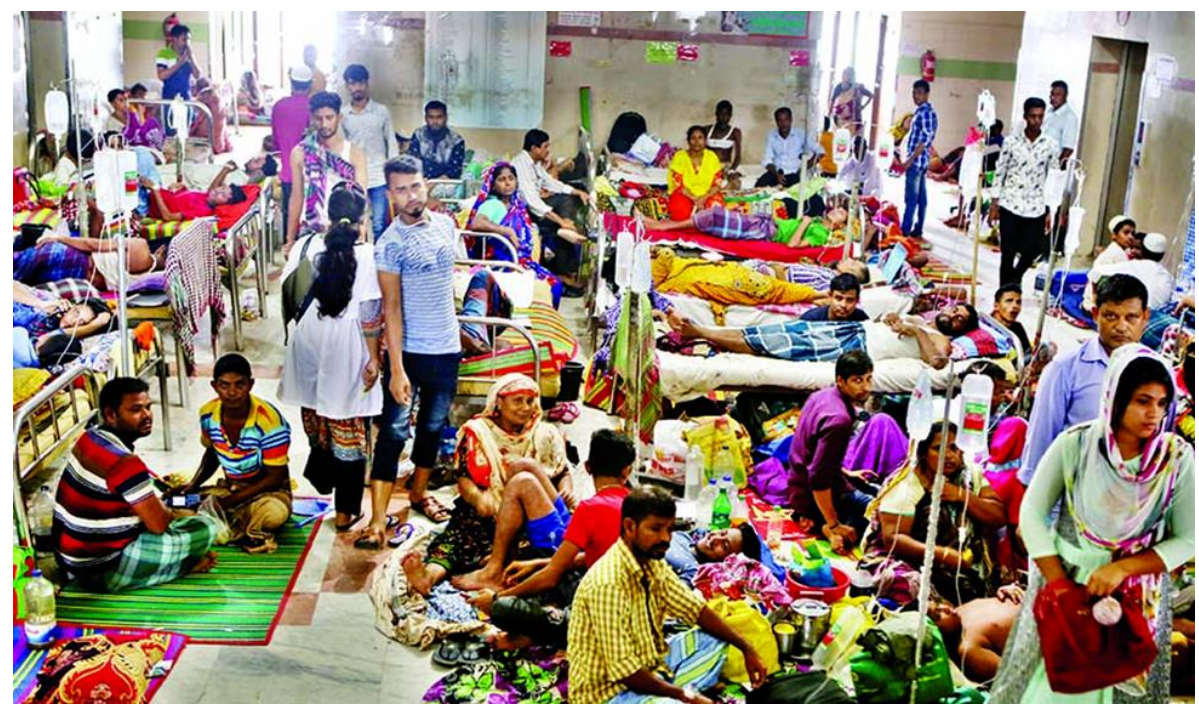

Figure 1. Patients' Struggle in a Bangladeshi Public Medical College Indoor [36-41]

Unsurprisingly, loss of life due to "wrong treatment" or medical negligence and doctors' incompetence have been reported in the media all the year-round. Laws such as the Penal Code 1860, Code of Criminal Procedure 1898, Consumer Rights Protection Act, 2009 underneath which cases can be filed for criminal remedies. In the match of dying due to medical negligence, cases may be filed under the penal code, 1860, as death via negligence is a crook offence and is punishable beneath area 304A of the penal code. There are additionally provisions for imprisonment and quality which are equally relevant to both the medical practitioner and the complainants. In the realm of therapeutic care, challenges are: public hospitals face no competition, have neither built-in incentive gadget nor any tradition to put in force self-discipline and habits guidelines and punish the recalcitrant; there is no mechanism either to evaluate individual's overall performance or that of any healthcare institution. Doctors generally give little time, frequently less than one minute, to take a look at patients and mistreat them; fixated mind-set of medical institution workforces who overestimate their very own performance, care little about the patients' experiences and don't be aware of that patients' satisfaction index is related to medical outcome.

\section{System Collision with Traditional Medicine}

There are around 86,000 villages in the us of a and almost each village has one or two common practitioners [42]. Over $65 \%$ of the population of Bangladesh obtain first-line healthcare offerings exceptionally from village medical practitioner [43]. two An estimated $70 \%$ to $75 \%$ human beings of the united states of america use ordinary medicinal drug for their healthcare [44, 45]. Also, 70\% of the ladies used at least one herbal product during their closing pregnancy, primarily besides session of a certified healthcare practitioner [30]. Again, alternative/traditional remedy are no longer protected in the scientific college curriculum besides in Ayurvedic Medical College of Bangladesh. Illiteracy, poor monetary status, cultural context, unpredictable prognosis and treatment cost, absenteeism of medical practitioner in rural fitness complexes, divergent medical opinions, unhealthy competition between health companies and their tendency to linger cure procedure, poor grasp of highly-priced medical assessments and unnecessary meals dietary supplements as nicely as easy availability and accessibility of choice medicinal drug diverted the sufferers to searching for assist from orthodox to choice remedy two [46-52].

\section{Drug Cost Vs OOP Expenditures}

Due to high competition in the pharmaceutical industry, aggressive advertising and marketing techniques have been adopted through the distinct medicine companies. The doctors, willingly or unwillingly, become phase of the system with few exceptions. This unethical promotion honestly drives them towards prescribing high valued or needless medicines [53-59]. Very often, medical representatives rush at top hours and aggressively pulls patient prescriptions in the identify of survey. Prescribing antibiotics

Int. J. Public Health Sci, Vol. 9, No. 1, March 2020: $34-45$ 
in $44 \%$ consultations, prescribing of 3 or extra drugs in $46 \%$ in city centers and $33 \%$ in neighborhood fitness facilities [29] truly elevate OOP expenditure and create sturdy repulsion in the direction of modern-day remedy the place almost $22 \%$ of the populace is under poverty line [60,61]. Moreover, medical doctors are more often accused to take $30 \%$ to $50 \%$ commission on a test from hospitals/diagnostic facilities [51, 62, 63]. Neither the regulatory authority nor the professional or customer rights our bodies has any position to manage or rectify the technique [53]. Annually around 3.5\% households (corresponding to approximately 5 million people) are pushed into poverty due to OOP outlays wherein continual non-communicable diseases are the principle contributor $[64,65]$. Khan et.al, 2017 further revealed that households spend $11 \%$ of their total budget on healthcare wherein $9 \%$ households faced financial catastrophe, wherein $16.5 \%$ of poorest and $9.2 \%$ of the richest households faces catastrophic health expenditure [65]. Studies reported that detrimental coping strategies and lack of healthcare expenditure protection for health care often negatively affect future income and can magnify people's vulnerability and hardship [66].

\section{Downgrading Image of Supplied Medicines}

Fake drugs kill more than 250,000 children a year worldwide [67]. Ensuring quality health service is impossible without availability of medicines because it is one among the essential requirements of individuals, said former DGDA of Bangladesh [68]. Counterfeit medicines may cause avoidable morbidity, mortality, drug resistance, early death or treatment failure, also as loss of religion in health systems, especially in low-income and middle-income countries [69]. Rural people, who are believed to be unaware of things are generally the victims of the adulterated medicines. "People are taking poison without knowing it," consistent with the Dean, faculty of Pharmacy at the Dhaka University, who noted sales of counterfeit or sub-standard medicines are commonest in rural areas thanks to the lower levels of health awareness and formal education there [70]. consistent with a survey by Bangabandhu Sheikh Mujib Medical University, as many as 2,700 children died thanks to kidney failure after taking toxic syrup from 1982 to 1992 . The accused companies took a more reasonable approach. Recognizing that $90 \%$ of their products had no scientific validity, they argued that the fault lay with the Drug Administration which shouldn't have permitted their products within the first place [71]. Recently, tons of individuals are being cheated in buying adulterated insulin [72]. consistent with the drug market intelligence, an estimated Tk 600 crore of counterfeit medicines is traded within the Tk 18,000 crore medicine market in Bangladesh annually [73-75]. the govt revoked licenses of 20 pharmaceutical companies for producing adulterated and low-quality medicine back in 2016 [76]. Besides those, the parliamentary panel recommended that licenses of 14 companies to manufacture antibiotics (penicillin, non-penicillin and cephalosporin groups) be revoked and permission of twenty-two companies to supply medicine of penicillin and cephalosporin groups be suspended [54, 77-82]. The court also ordered the government to immediately stop these conglomerates from manufacturing drugs. But the government is yet to act on it. 370 cases of fake medicines had been filed in the first 6 months of 2019, according to the DGDA [83]. Even hospitals like Apollo and United, were accused for keeping and selling of substandard reagents and drugs [54]. It should be further noted that, there are two Govt. Drug Testing Laboratories in the country, one unit in Chittagong and another in Dhaka $[84,85]$. They are fully-equipped with modern machines and other testing facilities but their performance is much lower than $(5 \%$ of the total produce) present demand where there are more than 275 pharmaceuticals companies have more than 25,000 brands that produce more than 100,000 batches of medicines [86].

\section{Quality of Medical education}

In a parliamentary session June 2019, the Health Minister informed that on the brink of 50\% teaching positions are vacant publicly medical and dental colleges, where most of the vacant posts are of the essential subjects $[87,88]$. The disappointing poor performance of the private medical colleges noted from the honorable prime minister during a seminar on critical disease treatment in Bangladesh [89]. A deficit in $65 \%$ teaching staffs in both public and personal medical colleges has also been reported [90]. Generally, $80 \%$ of medical education should be provided to students through practical classes-the rest is theoretical knowledge. But in some private medical colleges, students don't get to ascertain patients even in their fourth year [91]. Doctors without adequate practical and field-based applied knowledge are increasingly become risk factors to the patients they happen to treat. If a degree-holding doctor fails to seek out the vein for just a saline push-in then takes the professional help of an experienced nurse it's a shame not just for the doctor in question but also for the entire nation. Definitely of these facts have deep connections to progression of medical studies and quality of future doctors in Bangladesh. 


\section{Debasement of Health Providers' Image}

Bangladesh suffers from a severe lack of quality, reliable health care services and an insufficient supply of healthcare organizations to match growing demand. Specifically, there's a serious supply gap between the care available to the poor and therefore the rich, especially in light of the growing bourgeoisie a serious finding from the household survey was that patients are dissatisfied with the way doctors in government facilities behave towards them. The behavior of doctors towards them is one among the most determinants of satisfaction of state health service users [92]. Though private hospitals and clinics have mushroomed within the country over the years the standard of services delivered by most of these is found to be poor. Surprisingly, quite $40 \%$ of personal hospitals, clinics, blood banks and diagnostic centers aren't registered with the relevant agency [93]. Patients and their families are found to be more appreciative of the services offered by doctors, nurses and other medical staff of foreign hospitals. They find doctors there especially communicative and caring [94]. the amount of hospitals of international or regional standard is sort of a couple of and people are located only in Dhaka. Other cities and towns don't have modern health facilities in their true sense. Taking hostage of dead bodies for not clearing the hospitalization costs by a number of the hospitals is becoming quite common [95-99]. Other allegations also include such as: swapping of a deceased child with a replacement born baby, abducting or stealing neonate [100-102], staff not getting to patients in coma, high ICU [103,104], keeping clinically dead patients in ICU and raising hospital bill [105, 106], wrong diagnosis and treatment [107-114], absence of human touch and care from the hospital staff, not maintaining proper medical record or lack of electronic health record (EHR) or illegible prescription writing [115-125] etc. Hospital acquired infection rates in Bangladesh may exceed 30\% in some hospitals, according to Shahida et.al, 2016 [126]. Also, rural practitioners routinely made errors in death certification practices (more than 95\%) and medical record quality was poor (more than 70\%) [127]. The country has still not introduced the subject of Emergency and Critical care medicine in the curriculum 1 for graduate medical students. The Basic and Advanced life support courses are still not introduced as integral part of physician credentials in our hospitals, especially for those who work in Medicine, Pediatrics, Anesthesia, Emergency etc. Emergency health care exists in name not in real sense [128].

\section{Present Trend of Medical Tourism}

In a press briefing, former health minister of Bangladesh revealed four reasons of Bangladeshi patients seeking medical treatment in abroad (economic solvency, love for treatment abroad, health tourism, and in some cases, for the shortage of suitable treatment facilities within the country) but he couldn't present any statistics about what percentage people go abroad from Bangladesh for treatment and therefore the expenditure involved [129]. However, public health experts, health economists, agents of foreign specialized hospitals and patients revealed that Bangladeshi patients seeking treatment abroad is on an upward trend since patients are unwilling to gamble with their life and health. "People do everything they will to urge an accurate diagnosis. They run from one doctor to a different, change hospitals then on. Eventually they get frustrated once they don't see results. That's why people plan to go abroad for treatment," consistent with director of the Institute of Health Economics at Dhaka University [130]. A coffee confidence on local doctors and flawed diagnosis are forcing an outsized number of Bangladeshis to travel abroad for treatment of medical conditions like cancer, cardiac ailment, autism, infertility, also as medical check-ups. In financial year 2015-16, 165,000 patients from Bangladesh visited different hospitals of India but only around 58,000 medical visas were issued to Bangladeshi nationals. Some 63,000-65,000 patients visited Thailand in 2015 [131, 132]. On a mean 1,000 Bangladeshis attend India daily and a few 10,000 in Malaysia (in a year) to require treatment, as reported by 2 directors of Indian and Malaysian consultancy firms [133]. India, Thailand, Singapore and Malaysia are the foremost visited countries by Bangladeshis medical tourists. rather than playing the blame game, doctors should act responsibly and government should acknowledge its huge responsibility for updating the healthcare sector, consistent with Joint Secretary General, Diabetic Association of Bangladesh (BADAS) and convener of National Health Rights Movement [130]. For Bangladesh's economy, increasing medical tourism means the country economy is losing the amount of money Bangladeshis are spending abroad. About 700,000 people go to abroad every year for treatment spending US\$ 3.5-4.0 billion during the period 2018-2019 which was \$ 2.0 billion in 2012, due to lack of confidence on the local physicians and poor diagnosis system [94, 132]. The middle and lower middleclass families, in many cases, are forced to sell their property or spend life's savings or borrow from others to meet medical expenses abroad. This also drainage hard-earned foreign currency at the same time Bangladesh is becoming health tourism market for neighboring countries. To cash in on the ongoing demand from Bangladesh's rising mid-income population, some hospitals of India, Thailand, Singapore and Malaysia have either opened their liaison offices or hooked clients through their consultants in Bangladesh [133].

Int. J. Public Health Sci, Vol. 9, No. 1, March 2020: $34-45$ 


\section{CONCLUSION}

Privatization not only makes services more expensive, but also diminishes equity and accountability in the provision of services. The public sector should remain vital, and the government must remobilize it to provide better provision of healthcare. However, problems such as a lack of personnel, absenteeism, and corruption in the public sector have also contributed to private sector growth. At the same time, affordable formal primary care services are scarce, and what exists is almost exclusively provided by NGOs working on a project basis. NGOs, private organizations and mobile companies also are providing e-Health services to the patients in several areas in Bangladesh. it's important to possess modern hospitals in divisional and district headquarters. But, unwillingness of skilled and senior health professionals to figure outside Dhaka seems to be a serious problem here. As if to follow their footsteps even junior doctors despise postings beyond the capital city. A study on career choices among medical students in Bangladesh revealed that quite 50\% respondents wanted to practice abroad about $90 \%$ chose major cities as practice locations. consistent with another study, female medical students face challenges from the society also because the family. After marriage, their husbands and in-laws expect them to prioritize their families over their career. These clearly reveal motivation level of qualified doctors having posting in remote areas. It's time the authorities act pragmatically on policies to make female-friendly workplaces everywhere. Specialists and attendants are typically demotivated by poor working conditions, out of line treatment, and absence of vocation movement; private and inadequate experts tried to satisfy patients as against giving medicinally suitable consideration. Be that because it may, alluring facilities may bait senior health experts to urban communities and towns but Dhaka. a strong surveillance is important for assessing the general public health situation in Bangladesh and prompt notification of public health emergency. The relevant policymakers do got to check out the difficulty seriously, if they're really interested to prevent outflow of funds on account of medical treatment abroad and ensure proper health treatment in homeland.

\section{Recommendation}

Training of doctors/ nurses and paramedics may be a sine quo non for improving both preventive and therapeutic care. So, arrangements should be made to coach round-the-year two categories of health staff- doctors and nurses belonging to first category to receive training in healthcare management/administration and therefore the second category comprising of village quacks and SSC/HSC passed young men/women to receive training in preventive and first therapeutic care in their respective Thana Health Complex and be designated as village doctor (VHW) to figure in their own village. a number of the ladies will receive training in midwifery and be designated as birth attendant. The training of doctors/nurses will focus, inter alia, on patient-safety and patient-centered-care, during which healthcare is conceived of as a partnership between patients and health professionals. Doctors are going to be motivated to get feedback from patients about their experience. Hospital administration should lay down protocols for all procedures and surgeries, and standardize treatments. Nurses are going to be trained to affix in every ward check-lists like hand-washing/ alcohol rubs, use sanitized gowns and gloves and stress on cleanliness. VHWs and Birth Attendants educate patients and their families, among other things, on the way to maintain healthiness, nutrition level and maintain families' health record. Nurses are often relieved of additional duties by appointing ward clerks. Building on further institutional capacity would be subsequent step within the thanks to improving healthcare. National Health Council (NHC), which is to be headed by the Prime Minister, can provide policy directions and evaluate overall progress in healthcare. the govt can constitute a National Accreditation Council with the health minister at the helm and make accreditation a compulsory requirement for all hospitals, and other healthcare providers maintain a minimum standard. A patient and family advisory council are often constituted for all hospitals, which can lookout of patients' concerns including unnecessary diagnostic tests and procedures and coordinate with management board of hospitals.

\section{ACKNOWLEDGEMENTS}

I am thankful to Dr. Afsana Afroz, Department of Epidemiology and Preventive Medicine, School of Public Health and Preventive Medicine, Monash University, Melbourne, Australia for her valuable time to audit my paper and for her thoughtful suggestions. I am also grateful to seminar library of Faculty of Pharmacy, University of Dhaka and BANSDOC Library, Bangladesh for providing me books, journal and newsletters. The author declares that he has no competing interests. 


\section{REFERENCES}

[1] Star Online Report, "80 lakh Bangladeshis suffering from diabetes: State minister," The Daily Star, April 06, 2016.

[2] Islam FM, Chakrabarti R, Islam MT, Wahab M, Lamoureux E, Finger RP, Shaw JE., "Prediabetes, diagnosed and undiagnosed diabetes, their risk factors and association with knowledge of diabetes in rural Bangladesh: The Bangladesh Population-based Diabetes and Eye Study," J Diabetes., vol. 8, no. 2, pp. 260-8, Mar 2016. doi: 10.1111/1753-0407.12294

[3] Fottrell, Edward et al., "Community groups or mobile phone messaging to prevent and control type 2 diabetes and intermediate hyperglycaemia in Bangladesh (DMagic): a cluster-randomised controlled trial," The lancet. Diabetes \& endocrinology, vol. 7, no. 3, pp. 200-212, 2019. doi:10.1016/S2213-8587(19)30001-4

[4] Shariful Islam, Sheikh Mohammed et al., "Healthcare use and expenditure for diabetes in Bangladesh," BMJ global health vol. 2, no. 1, Jan. 2017. doi:10.1136/bmjgh-2016-000033

[5] Das H, Banik S., "Prevalence of dyslipidemia among the diabetic patients in southern Bangladesh: A cross-sectional study,” Diabetes Metab Syndr, vol. 13, no. 1, pp. 252-257, 2019. doi: 10.1016/j.dsx.2018.09.006.

[6] Mohammad QD, Habib M, Mondal BA, Chowdhury RN, Hasan MH, Hoque MA, Rahman KM, Khan SU, Chowdhury AH, Haque B., "Stroke in Bangladeshi patients and risk factor," Mymensingh Med J., vol. 23, no. 3, pp.9-520, 2014.

[7] Afroz A, Zhang W, Wei Loh AJ, Jie Lee DX, Billah B., "Macro- and micro-vascular complications and their determinants among people with type 2 diabetes in Bangladesh," Diabetes Metab Syndr. Vol. 13, no. 5, pp. 2939-2946. doi: 10.1016/j.dsx.2019.07.046

[8] National Institute of Health (UK), “ Stay on TRACK To Prevent Blindness From Diabetes,” [Online], Available: From: https://www.nei.nih.gov/sites/default/files/nehep-pdfs/NDM_SM_Toolkit_2015.pdf

[9] American Association of Diabetes Educators. Resources for People Living with Diabetes (Monitoring). [Online], Available: From: https://www.diabeteseducator.org/living-with-diabetes/aade7-self-care-behaviors/aade7-self-carebehaviors-monitoring

[10] Mohiuddin AK., "Domination of Nephrotic Problems among Diabetic Patients of Bangladesh," Archives of Nephrology and Urology, vol. 1, pp. 009-016., 2018. DOI: 10.26502/anu.2644-2833002

[11] Vanderlee L, Ahmed S, Ferdous F, Farzana FD, Das SK, Ahmed T, Hammond D, Faruque ASG., "Self-care practices and barriers to compliance among patients with diabetes in a community in rural Bangladesh," Int $J$ Diabetes Dev Ctries, pp. 36: 320, 2016. DOI: 10.1007/s13410-015-0460-7

[12] Azad A. "How climate change will affect your health," CNN health, October 2018.

[13] Diabetic Association of Bangladesh, "WDF-494 Extension of Diabetic Retinopathy Care in Bangladesh,"[Online], Available: from: https://www.dab-bd.org/sub-page.php?sub_category=35

[14] Azad, Kishwar, "Type 1 diabetes: The Bangladesh perspective," Indian journal of endocrinology and metabolism vol. 19, no. 1, pp. 09-11, 2015. doi:10.4103/2230-8210.155344

[15] Alam MM, Hawlader MDH, Wahab A, Hossain MD, Nishat SA, Zaman S, Ahsan GU., "Determinants of overweight and obesity among urban school-going children and adolescents: a case-control study in Bangladesh,” Int J Adolesc Med Health, 2019 doi: 10.1515/ijamh-2018-0034.

[16] Al Muktadir MH, Islam MA, Amin MN, Ghosh S, Siddiqui SA, Debnath D, Islam MM, Ahmed T, Sultana F., "Nutrition transition - Pattern IV: Leads Bangladeshi youth to the increasing prevalence of overweight and obesity," Diabetes Metab Syndr., vol. 13, no. 3, pp. 1943-1947, 2019. doi: 10.1016/j.dsx.2019.04.034

[17] Goon S, Bipasha MS, Islam S., "Fast food consumption and obesity risk among university students of Bangladesh," Eur J Prev Med., 2014. 2:99e104

[18] World Diabetes Day 2018, “Access to insulin is a human right” In conversation with Professor AK Azad Khan, President, Diabetic Association of Bangladesh, The Daily Star, November, 2018.

[19] Hasib NI. Children getting type 2 diabetes 'alarmingly' in Bangladesh. bdnews24.com 06 April, 2016.

[20] Hossain MS, Siddiqee MH, Ferdous S, Faruki M, Jahan R, Shahik SM, Raheem E, Okely AD., "Is Childhood Overweight/Obesity Perceived as a Health Problem by Mothers of Preschool Aged Children in Bangladesh? A Community Level Cross-Sectional Study," Int J Environ Res Public Health, vol. 1, no. 2, 2019. pii: E202. doi: 10.3390/ijerph16020202.

[21] Chaity AJ., "Obesity blamed for alarming rise in childhood diabetes," DhakaTribune November 2017.

[22] Bipasha M, Goon S. "Fast food preferences and food habits among students of private universities in Bangladesh," South East Asia Journal of Public Health, vol. 3, no. 1, pp. 61-64, 2014. DOI: 10.3329/seajph.v3i1.17713

[23] Hoque ME, Long KZ, Niessen LW, Al Mamun A., "Rapid shift toward overweight from double burden of underweight and overweight among Bangladeshi women: a systematic review and pooled analysis," Nutr Rev. vol. 73, no. 7, pp. 438-47. doi: 10.1093/nutrit/nuv003.

[24] Tanwi, Tania Sultana et al. "Socioeconomic correlates of overweight and obesity among ever-married urban women in Bangladesh,” BMC public health , vol. 19, no. 1, pp. 842, 2019. doi:10.1186/s12889-019-7221-3 
[25] Banik S, Rahman M., "Prevalence of Overweight and Obesity in Bangladesh: a Systematic Review of the Literature," Curr Obes Rep., vol. 7, no. 4, pp. 247-253, 2018. doi: 10.1007/s13679-018-0323-x

[26] Biswas, Tuhin et al., "The prevalence of underweight, overweight and obesity in Bangladeshi adults: Data from a national survey," PloS one, vol. 12, 2017. doi:10.1371/journal.pone.0177395

[27] Chowdhury, Muhammad Abdul Baker et al., "Trends, prevalence and risk factors of overweight and obesity among women of reproductive age in Bangladesh: a pooled analysis of five national cross-sectional surveys," BMJ open vol. 8, no.7, Jul. 2018. doi:10.1136/bmjopen-2017-018468

[28] Biswas T, Uddin MJ, Mamun AA, Pervin S, P Garnett S., "Increasing prevalence of overweight and obesity in Bangladeshi women of reproductive age: Findings from 2004 to 2014," PLoS One, vol. 12, no. 7, 2017. doi: 10.1371/journal.pone.0181080.

[29] Guthold R, Stevens GA, Riley LM, Bull FC. Worldwide trends in insufficient physical activity from 2001 to 2016: a pooled analysis of 358 population-based surveys with 1.9 million participants. Lancet Glob Health. 2018 Oct; 6(10): e1077-e1086. DOI: 10.1016/S2214-109X(18)30357-7.

[30] Mahbub I. "Why Is Diabetes on The Rise in Bangladesh? Web Future Startup October 25, 2016,"[Online], Available: https://futurestartup.com/2016/10/25/why-is-diabetes-on-the-rise-in-bangladesh/

[31] Tareq S., "Obesity is increasing among the younger generation in Bangladesh," The Daily Star September, 2018.

[32] Uddin R, Khan A, Burton NW., "Prevalence and sociodemographic patterns of physical activity among Bangladeshi young adults," J Health Popul Nutr., vol. 36, no. 1, pp. 31, 2017. doi: 10.1186/s41043-017-0108-y

[33] Moniruzzaman, Mohammad et al., "Physical activity levels and associated socio-demographic factors in Bangladeshi adults: a cross-sectional study," BMC public health, vol. 17, no. 1, Jan. 2017, doi:10.1186/s12889-016-4003-Z

[34] Vancampfort D, Firth J, Schuch F, Rosenbaum S, De Hert M, Mugisha J, Probst M, Stubbs B., "Physical activity and sedentary behavior in people with bipolar disorder: A systematic review and meta-analysis," J Affect Disord., vol. 201, pp. 145-52, 2016. doi: 10.1016/j.jad.2016.05.020.

[35] Bishwajit, Ghose et al. "Physical inactivity and self-reported depression among middle- and older-aged population in South Asia: World health survey,” BMC geriatrics, vol. 17, 1 100, Apr. 2017, doi:10.1186/s12877-017-0489-1

[36] Ali, Nausad et al., "Sex-specific prevalence, inequality and associated predictors of hypertension, diabetes, and comorbidity among Bangladeshi adults: results from a nationwide cross-sectional demographic and health survey," BMJ open, vol. 9, no, 9, 2019, doi:10.1136/bmjopen-2019-029364

[37] Mohiuddin AK., "Diabetes Fact: Bangladesh Perspective," International Journal of Diabetes Research, vol. 2, no. 1, pp. 14-20, 2019. [Online], Available from: URL: http://www.ghrnet.org/index.php/ijhr/article/view/2457 doi: 10.17554/j.issn.2414-2409.2019.02.12

[38] Afroz, Afsana et al. "Type 2 diabetes mellitus in Bangladesh: a prevalence based cost-of-illness study," BMC health services research, vol. 19, no. 1, pp. 601, 2019, doi:10.1186/s12913-019-4440-3

[39] Islam, Jessica Yasmine et al. "Prevalence and determinants of hyperglycaemia among adults in Bangladesh: results from a population-based national survey," BMJ open, vol. 9, no. 7, 2019. doi:10.1136/bmjopen-2019-029674

[40] Salahuddin T., "The rising threat of NCDs in Bangladesh," The Daily Star, January 2019.

[41] Salahuddin T., "Obesity is increasing among the younger generation in Bangladesh," The Daily Star, September 2018.

[42] WHO Bangladesh, "Double trouble: diabetes and depression," [Online], Available: http://www.searo.who.int/bangladesh/depressiondoubletrouble/en/

[43] Aowsaf SMA, "Diabetes management service launched in Bangladesh,” DhakaTribune, September, 2018.

[44] Fottrell, Edward et al., "Diabetes knowledge and care practices among adults in rural Bangladesh: a cross-sectional survey,” BMJ global health, vol. 3, no. 4, Jul. 2018. doi:10.1136/bmjgh-2018-000891

[45] Fottrell, Edward. et al., "Distribution of diabetes, hypertension and non-communicable disease risk factors among adults in rural Bangladesh: a cross-sectional survey," BMJ global health, vol. 3, no. 6, Nov. 2018. doi:10.1136/bmjgh-2018-000787

[46] Palma P., “A worrying picture of diabetes in Bangladesh,” The Daily Star, November 2018.

[47] Health Tips., "Screening reduces mortality for detectable type 2 diabetics," The Daily Star, August 2017.

[48] Hasan MK., "WHO: Tobacco responsible for 1 in 5 deaths in Bangladesh,” DhakaTribune, June 01, 2018.

[49] Bergman, Bryan C et al., "Novel and reversible mechanisms of smoking-induced insulin resistance in humans," Diabetes, vol. 61, no. 12, pp. 3156-66, 2012. doi:10.2337/db12-0418

[50] Kong C, Nimmo L, Elatrozy T, Anyaoku V, Hughes C, Robinson S, Richmond W, Elkeles RS., "Smoking is associated with increased hepatic lipase activity, insulin resistance, dyslipidaemia and early atherosclerosis in Type 2 diabetes," Atherosclerosis, vol. 156, no. 2, pp. 373-8, 2001.

[51] Schofield, Jonathan D et al. "Diabetes Dyslipidemia." Diabetes therapy : research, treatment and education of diabetes and related disorders, vol. 7, no. 2, pp. 203-19, 2016. doi:10.1007/s13300-016-0167-x 
[52] Facchini FS, Hollenbeck CB, Jeppesen J, Chen YD, Reaven GM., "Insulin resistance and cigarette smoking," Lancet, vol. 339, no. 8802, pp. 1128-30, 1992.

[53] Bajaj, Mandeep. "Nicotine and insulin resistance: when the smoke clears." Diabetes vol. 61,12 (2012): 3078-80. doi: $10.2337 / \mathrm{db} 12-1100$

[54] Harris, Kindred K et al. "Metabolic effects of smoking cessation.” Nature reviews. Endocrinology vol. 12,5 (2016): 299-308. doi:10.1038/nrendo.2016.32

[55] Calcaterra V, Winickoff JP, Klersy C, Schiano LM, Bazzano R, Montalbano C, Musella V, Regalbuto C, Larizza D, Cena H. Smoke exposure and cardio-metabolic profile in youth with type 1 diabetes. Diabetol Metab Syndr. 2018 Jul 6;10:53. doi: 10.1186/s13098-018-0355-0.

[56] Rao Ch, Srinivasa, and Emmanuel Subash Y., "The effect of chronic tobacco smoking and chewing on the lipid profile," Journal of clinical and diagnostic research : JCDR, vol. 7, no. 1, pp. 4-31. doi:10.7860/JCDR/2012/5086.2663

[57] Gossett, Linda K et al. "Smoking intensity and lipoprotein abnormalities in active smokers." Journal of clinical lipidology vol. 3, no. 6, pp. 8-372, 2009. doi:10.1016/j.jacl.2009.10.008

[58] Wasifuzzaman C., "A review of prevalence, complications, risk factors, knowledge assessment, self-management, consciousness and treatment of diabetes mellitus in Bangladesh," [Online] Available: http://dspace.bracu.ac.bd/xmlui/handle/10361/10674

[59] Nargis, Nigar et al. "A decade of cigarette taxation in Bangladesh: lessons learnt for tobacco control." Bulletin of the World Health Organization vol. 97, no. 3, pp. 221-229, 2019. doi:10.2471/BLT.18.216135

[60] Alam, Dewan S et al., "Smoking-attributable mortality in Bangladesh: proportional mortality study," Bulletin of the World Health Organization, vol. 91, no. 10, pp. 757-64, 2013. doi:10.2471/BLT.13.120196

[61] Nargis, Nigar et al. "Prevalence and Patterns of Tobacco Use in Bangladesh from 2009 to 2012: Evidence from International Tobacco Control (ITC) Study," PloS one, vol. 10, no. 11, Nov. 2015. doi:10.1371/journal.pone.0141135

[62] Khan MK, Hoque HE, Ferdous J., "Knowledge and Attitude Regarding National Tobacco Control Law and Practice of Tobacco Smoking among Bangladesh Police," Mymensingh Med J., vol. 28, no. 4, pp. 752-761.

[63] Tribune Desk., "Temperature in Bangladesh to rise to deadly heights by end of century," DhakaTribune, 2017.

[64] Mohiuddin AK. "Domination of Pollutant Residues among Food Products of South-East Asian Countries," South Asian Res J Agri Fish, vol-1, no. 2, pp. 50-53, 2019. DOI: 10.36346/sarjaf.2019.v01i02.003

[65] Paul SK, Islam MS, Hasibuzzaman MM, Hossain F, Anjum A, Saud ZA, Haque MM, Sultana P, Haque A, Andric KB, Rahman A, Karim MR, Siddique AE, Karim Y, Rahman M, Miyataka H, Xin L, Himeno S, Hossain K. Higher risk of hyperglycemia with greater susceptibility in females in chronic arsenic-exposed individuals in Bangladesh. Sci Total Environ. 2019 Jun 10;668:1004-1012. doi: 10.1016/j.scitotenv.2019.03.029.

[66] Chaity AJ., "15\% pregnant women diagnosed with diabetes," DhakaTribune, November 2017.

[67] Goon S, Islam MS. "Breakfast skipping and obesity risk among urban adults in Bangladesh," Int J Public Health Sci. vol. 3, pp. 15-22, 2014.

[68] Khan A, Khan SR, Burton NW., "Missing breakfast is associated with overweight and obesity in Bangladeshi adolescents," Acta Paediatr, vol. 108, no. 1, pp. 178-179, 2019. doi: 10.1111/apa.14553.

[69] Kabir A, Miah S, Islam A., "Factors influencing eating behavior and dietary intake among resident students in a public university in Bangladesh: A qualitative study," PLoS One, vol. 13, no. 6, 2018. doi: 10.1371/journal.pone.0198801.

[70] Mohiuddin, A., "Skipping Breakfast Everyday Keeps Well-Being Away," Acta Medica, vol. 50, no. 1, pp. 26-33, Mar. 2019. doi:10.32552/2019.ActaMedica.331.

[71] Bener A, Yousafzai MT., "Effect of Ramadan fasting on diabetes mellitus: a population-based study in Qatar," J Egypt Public Health Assoc., vol. 89, no. 2, pp. 47-52, 2014. doi: 10.1097/01.EPX.0000451852.92252.9b.

[72] Yeoh EC, Zainudin SB, Loh WN, Chua CL, Fun S, Subramaniam T, Sum CF, Lim SC., "Fasting during Ramadan and Associated Changes in Glycaemia, Caloric Intake and Body Composition with Gender Differences in Singapore," Ann Acad Med Singapore, vol. 44, no. 6, pp. 202-6, 2015.

[73] Bener, Abdülbari et al., "Effect of ramadan fasting on glycemic control and other essential variables in diabetic patients," Annals of African medicine, vol. 17, no. 4, pp. 196-202, 2018. doi:10.4103/aam.aam_63_17

[74] Bener A, A Al-Hamaq AOA, Öztürk M, Çatan F, Haris PI, Rajput KU, Ömer A., "Effect of ramadan fasting on glycemic control and other essential variables in diabetic patients," Ann Afr Med., vol. 17, no. 4, pp. 196-202, 2018. doi: 10.4103/aam.aam_63_17.

[75] Ahmed, Mohamed H et al. "Diabetes and Ramadan: A concise and practical update," Journal of family medicine and primary care vol. 6, no. 1 pp. 11-18, 2017. doi:10.4103/2249-4863.214964

[76] Malinowski, Bartosz et al. "Intermittent Fasting in Cardiovascular Disorders-An Overview," Nutrients, vol. 11, no. 3 pp. 673. 20 Mar. 2019, doi:10.3390/nu11030673

Int. J. Public Health Sci, Vol. 9, No. 1, March 2020: $34-45$ 
[77] Siaw, Melanie Y L et al., "Metabolic parameters in type 2 diabetic patients with varying degrees of glycemic control during Ramadan: An observational study,” Journal of diabetes investigation vol. 7, no. 1, pp. 5-70, 2016. doi:10.1111/jdi.12374

[78] Khaled, Boumédiène Méghit, and Slimane Belbraouet, "Effect of Ramadan fasting on anthropometric parameters and food consumption in 276 type 2 diabetic obese women," International journal of diabetes in developing countries, vol. 29, no. 2, pp.8-62, 2018. doi:10.4103/0973-3930.53122

[79] Ali, Sharique A et al., "Links between the Prophet Muhammad (PBUH) recommended foods and disease management: A review in the light of modern superfoods," International journal of health sciences vol. 12, no. 2 pp. 61-69, 2018.

[80] Mohiuddin, A. "The Mysterious Domination of Food/Drinking Water Contaminants and Adulterants in Bangladesh". PharmaTutor, Vol. 7, no. 1, Jan. 2019, pp. 42-58, doi:10.29161/PT.v7.i1.2019.42.

[81] Tan T, Zhang Y, Luo W, Lv J, Han C, Hamlin JNR, Luo H, Li H, Wan Y, Yang X, Song W, Tong Z. Formaldehyde induces diabetes-associated cognitive impairments. FASEB J. 2018 Jul;32(7):3669-3679. doi: 10.1096/fj.201701239R.

[82] Hipkiss, Alan R. "Depression, Diabetes and Dementia: Formaldehyde May Be a Common Causal Agent; Could Carnosine, a Pluripotent Peptide, Be Protective?." Aging and disease vol. 8,2 128-130. 1 Apr. 2017, doi:10.14336/AD.2017.0120

[83] Tulpule K, Dringen R. Formaldehyde in brain: an overlooked player in neurodegeneration? J Neurochem. 2013 Oct;127(1):7-21. doi: 10.1111/jnc.12356.

[84] Grotton C. Research Update: Protect Against Formaldehyde Exposure. Life Extension Magazine®, Issue: Jan 2019.

[85] Mohiuddin, A. K. (2019). Chemical Contaminants and Pollutants in the Measurable Life of Dhaka City. European Journal of Sustainable Development Research, 3(2), em0083. https://doi.org/10.29333/ejosdr/5727

[86] Ullah A. Sale of Adulterated Spice Powder: Public health at risk. The Daily Sun, October 16, 2019.

[87] Staff Correspondent. Food adulteration rings alarm bell: STAR-RDRS roundtable told most food items adulterated, pose lethal risks to public health. The Daily Star, August 11, 2011.

[88] Majed N, Real MIH, Akter Mand Azam HM (2016) Food Adulteration and Bio-Magnification of Environmental Contaminants: A Comprehensive Risk Framework for Bangladesh. Front.Environ.Sci.4:34. doi: 10.3389/fenvs.2016.00034

[89] Chowdhury MFI. Evaluating Position of Bangladesh to Combat 'Adulterated Food' Crisis in Light of Human Rights. OSR Journal Of Humanities And Social Science (IOSR-JHSS) Volume 19, Issue 3, Ver. VI (Mar. 2014), PP 45-54.

[90] Child Marriage in Bangladesh. Marry Before Your House is Swept Away. Human Rights Watch, June 9, 2015.

[91] Kamal SM, Hassan CH, Alam GM, Ying Y. Child marriage in Bangladesh: trends and determinants. J Biosoc Sci. 2015 Jan;47(1):120-39. doi: 10.1017/S0021932013000746.

[92] Hossain MG, Mahumud RA, Saw A. PREVALENCE OF CHILD MARRIAGE AMONG BANGLADESHI WOMEN AND TREND OF CHANGE OVER TIME. J Biosoc Sci. 2016 Aug;48(4):530-8. doi: $10.1017 /$ S0021932015000279.

[93] Zahangir, M S et al. "Malnutrition and non-communicable diseases among Bangladeshi women: an urban-rural comparison." Nutrition \& diabetes vol. 7,3 e250. 20 Mar. 2017, doi:10.1038/nutd.2017.2

[94] Silva-Zolezzi, Irma et al. "Maternal nutrition: opportunities in the prevention of gestational diabetes." Nutrition reviews vol. 75,suppl 1 (2017): 32-50. doi:10.1093/nutrit/nuw033

[95] Tunçer M, Tunçer M. Fetal malnutrition in infants born to diabetic mothers. Turk J Pediatr. 1982 OctDec;24(4):245-9.

[96] Independent Online Desk. Malnutrition major cause of premature child birth in Bangladesh. The Independent, 23 March, 2018.

[97] Das S, Mia MN, Hanifi SM, Hoque S, Bhuiya A. Health literacy in a community with low levels of education: findings from Chakaria, a rural area of Bangladesh. BMC Public Health. 2017 Feb 16;17(1):203. doi: 10.1186/s 12889-017-4097-y.

[98] Mehzabin, R., K. Hossain, M. Moniruzzaman, and S. K. J. Sayeed. "Association of Functional Health Literacy With Glycemic Control: A Cross Sectional Study in Urban Population of Bangladesh”. Journal of Medicine, Vol. 20, no. 1, Jan. 2019, pp. 19-24, doi:10.3329/jom.v20i1.38816.

[99] Islam FMA, Kawasaki R, Finger RP. Factors associated with participation in a diabetic retinopathy screening program in a rural district in Bangladesh. Diabetes Res Clin Pract. 2018 Oct;144:111-117. doi: 10.1016/j.diabres.2018.08.012.

[100] Siddique, Md Kaoser Bin et al. "Diabetes knowledge and utilization of healthcare services among patients with type 2 diabetes mellitus in Dhaka, Bangladesh.” BMC health services research vol. 17,1 586. 22 Aug. 2017, doi:10.1186/s12913-017-2542-3 
[101] Ahmed, Tahmeed et al. "Nutrition of children and women in Bangladesh: trends and directions for the future." Journal of health, population, and nutrition vol. 30,1 (2012): 1-11. doi:10.3329/jhpn.v30i1.11268

[102] Burton NW, Kadir MA, Khan A. Physical activity attitudes among adolescents in Bangladesh. Public Health. 2019 Nov 13;179:59-65. doi: 10.1016/j.puhe.2019.10.004.

[103] Rawlings GH, Williams RK, Clarke DJ, et al. Exploring adults' experiences of sedentary behaviour and participation in non-workplace interventions designed to reduce sedentary behaviour: a thematic synthesis of qualitative studies. BMC Public Health. 2019;19(1):1099. Published 2019 Aug 13. doi:10.1186/s12889-019-7365-1

[104] Neyazi SN. The Rise Of Joblessness Among The Youths In Bangladesh. FinTech, July 15, 2019.

[105] Aravinda J. Risk factors in patients with type 2 diabetes in Bengaluru: A retrospective study. World J Diabetes. 2019;10(4):241-248. doi:10.4239/wjd.v10.i4.241

[106] Foucaut AM, Faure C, Julia C, et al. Sedentary behavior, physical inactivity and body composition in relation to idiopathic infertility among men and women. PLoS One. 2019;14(4):e0210770. Published 2019 Apr 24. doi:10.1371/journal.pone.0210770

[107] Pati S, Lobo E, Pati S, Desaraju S, Mahapatra P. Type 2 diabetes and physical activity: barriers and enablers to diabetes control in Eastern India. Prim Health Care Res Dev. 2019;20:e44. Published 2019 Apr 29. doi:10.1017/S146342361800097X

[108] Kirk JK, Stegner J. Self-monitoring of blood glucose: practical aspects. J Diabetes Sci Technol. 2010;4(2):435439. Published 2010 Mar 1. doi:10.1177/193229681000400225.

[109] Janapala RN, Jayaraj JS, Fathima N, et al. Continuous Glucose Monitoring Versus Self-monitoring of Blood Glucose in Type 2 Diabetes Mellitus: A Systematic Review with Meta-analysis. Cureus. 2019;11(9):e5634. Published 2019 Sep 12. doi:10.7759/cureus.5634

[110] Chawla A, Chawla R, Jaggi S. Microvasular and macrovascular complications in diabetes mellitus: Distinct or continuum?. Indian J Endocrinol Metab. 2016;20(4):546-551. doi:10.4103/2230-8210.183480

[111] St Onge EL, Motycka CA, Miller SA. A review of cardiovascular risks associated with medications used to treat type-2 diabetes mellitus. P T. 2009;34(7):368-378.

[112] de la Monte SM. Insulin Resistance and Neurodegeneration: Progress Towards the Development of New Therapeutics for Alzheimer's Disease. Drugs. 2017;77(1):47-65. doi:10.1007/s40265-016-0674-0

[113] Jingi AM, Tankeu AT, Ateba NA, Noubiap JJ. Mechanism of worsening diabetic retinopathy with rapid lowering of blood glucose: the synergistic hypothesis. BMC Endocr Disord. 2017;17(1):63. Published 2017 Oct 10. doi:10.1186/s12902-017-0213-3

[114] Kiziltoprak H, Tekin K, Inanc M, Goker YS. Cataract in diabetes mellitus. World J Diabetes. 2019;10(3):140-153. doi:10.4239/wjd.v10.i3.140

[115] Rosen J, Yosipovitch G. Skin Manifestations of Diabetes Mellitus. [Updated 2018 Jan 4]. In: Feingold KR, Anawalt B, Boyce A, et al., editors. Endotext [Internet]. South Dartmouth (MA): MDText.com, Inc.; 2000-. Available from: https://www.ncbi.nlm.nih.gov/books/NBK481900/

[116] Mendes AL, Miot HA, Haddad V Junior. Diabetes mellitus and the skin. An Bras Dermatol. 2017;92(1):8-20. doi:10.1590/abd1806-4841.20175514

[117] Al Wahbi A. Autoamputation of diabetic toe with dry gangrene: a myth or a fact?. Diabetes Metab Syndr Obes. 2018;11:255-264. Published 2018 Jun 1. doi:10.2147/DMSO.S164199

[118] Fekadu G, Chelkeba L, Kebede A. Risk factors, clinical presentations and predictors of stroke among adult patients admitted to stroke unit of Jimma university medical center, south west Ethiopia: prospective observational study. BMC Neurol. 2019;19(1):187. Published 2019 Aug 7. doi:10.1186/s12883-019-1409-0

[119] Lau LH, Lew J, Borschmann K, Thijs V, Ekinci EI. Prevalence of diabetes and its effects on stroke outcomes: A meta-analysis and literature review. J Diabetes Investig. 2019;10(3):780-792. doi:10.1111/jdi.12932

[120] Chowdhury MZI, Yeasmin F, Rabi DM, Ronksley PE, Turin TC. Predicting the risk of stroke among patients with type 2 diabetes: a systematic review and meta-analysis of C-statistics. BMJ Open. 2019;9(8):e025579. Published 2019 Aug 30. doi:10.1136/bmjopen-2018-025579

[121] Aminde LN, Tindong M, Ngwasiri CA, et al. Adherence to antidiabetic medication and factors associated with nonadherence among patients with type-2 diabetes mellitus in two regional hospitals in Cameroon. BMC Endocr Disord. 2019;19(1):35. Published 2019 Apr 3. doi:10.1186/s12902-019-0360-9

[122] Alqarni AM, Alrahbeni T, Qarni AA, Qarni HMA. Adherence to diabetes medication among diabetic patients in the Bisha governorate of Saudi Arabia - a cross-sectional survey. Patient Prefer Adherence. 2018 Dec 24;13:63-71. doi: 10.2147/PPA.S176355.

[123] Brown T, Moore TH, Hooper L, Gao Y, Zayegh A, Ijaz S, Elwenspoek M, Foxen SC, Magee L, O'Malley C, Waters E, Summerbell CD. Interventions for preventing obesity in children. Cochrane Database Syst Rev. 2019 Jul 23;7:CD001871. doi: 10.1002/14651858.CD001871.pub4. 
[124] Gautam S, Jeong HS. Childhood Obesity and Its Associated Factors among School Children in Udupi, Karnataka, India. J Lifestyle Med. 2019;9(1):27-35. doi:10.15280/jlm.2019.9.1.27

[125] Brødsgaard A, Wagner L, Poulsen I. Childhood Overweight Dependence on Mother-Child Relationship. Health Psychol Res. 2014;2(2):1583. Published 2014 Sep 4. doi:10.4081/hpr.2014.1583

[126] Pi-Sunyer X. The medical risks of obesity. Postgrad Med. 2009;121(6):21-33. doi:10.3810/pgm.2009.11.2074.

[127] Moniruzzaman, M., et al. "Physical Activity Levels in Bangladeshi Adults: Results from STEPS Survey 2010." Public Health, W.B. Saunders, 7 Apr. 2016, https://www.sciencedirect.com/science/article/pii/S0033350616000858.

[128] Alsabieh M, Alqahtani M, Altamimi A, et al. Fast food consumption and its associations with heart rate, blood pressure, cognitive function and quality of life. Pilot study. Heliyon. 2019;5(5):e01566. Published 2019 May 17. doi:10.1016/j.heliyon.2019.e01566

[129] Bădescu SV, Tătaru C, Kobylinska L, et al. The association between Diabetes mellitus and Depression. J Med Life. 2016;9(2):120-125.

[130] Petrak F, Röhrig B, Ismail K. Depression and Diabetes. [Updated 2018 Jan 14]. In: Feingold KR, Anawalt B, Boyce A, et al., editors. Endotext [Internet]. South Dartmouth (MA): MDText.com, Inc.; 2000-. Available from: https://www.ncbi.nlm.nih.gov/books/NBK498652/

[131] Web WHO. Double trouble: diabetes and depression Country Of - fice for Bangladesh Available From: http://www.searo.who.int/ bangladesh/depressiondoubletrouble/en/

[132] Georges A, Galbiati L, Clair C. Smoking in men and women with type 2 diabetes: A qualitative gender-sensitive exploration of barriers to smoking cessation among people with type 2 diabetes. PLoS One. 2019;14(8):e0221783. Published 2019 Aug 28. doi:10.1371/journal.pone.0221783

[133] Nasiri-Amiri F, Sepidarkish M, Shirvani MA, Habibipour P, Tabari NSM. The effect of exercise on the prevention of gestational diabetes in obese and overweight pregnant women: a systematic review and meta-analysis. Diabetol Metab Syndr. 2019 Aug 27;11:72. doi: 10.1186/s13098-019-0470-6. 